\title{
Soil Arthropod Abundance and Diversity Following Land Application of Swine Slurry
}

\author{
Nicole R. Schuster ${ }^{1}$, Julie A. Peterson², John E. Gilley ${ }^{3}$, Linda R. Schott ${ }^{1}$, Amy M. Schmidt1,4* \\ ${ }^{1}$ Department of Biological Systems Engineering, University of Nebraska-Lincoln, Lincoln, NE, USA \\ ${ }^{2}$ Department of Entomology, University of Nebraska-Lincoln, North Platte, NE, USA \\ ${ }^{3}$ USDA-ARS, Lincoln, NE, USA \\ ${ }^{4}$ Department of Animal Science, University of Nebraska-Lincoln, Lincoln, NE, USA \\ Email: *aschmidt@unl.edu
}

How to cite this paper: Schuster, N.R., Peterson, J.A., Gilley, J.E., Schott, L.R. and Schmidt, A.M. (2019) Soil Arthropod Abundance and Diversity Following Land Application of Swine Slurry. Agricultural Sciences, 10, 150-163.

https://doi.org/10.4236/as.2019.102013

Received: January 26, 2019

Accepted: February 23, 2019

Published: February 26, 2019

Copyright (c) 2019 by author(s) and Scientific Research Publishing Inc. This work is licensed under the Creative Commons Attribution International License (CC BY 4.0).

http://creativecommons.org/licenses/by/4.0/

\section{Open Access}

\begin{abstract}
Soil arthropods play an important role in nutrient cycling and maintenance of soil structure, and their abundance and diversity provide an indication of the biological quality of soil. Land application of livestock manure provides crop nutrients and may also impact the soil arthropod community. This study was conducted to quantify soil arthropod abundance and diversity for a period of one year following swine manure application via broadcast or injection. Arthropods were extracted from plot soil samples using Berlese funnels, identified and counted, and the QBS index (Qualità Biologica del Suolo) was calculated for each soil sample. Collembola (Hypogastruridae and Isotomidae) populations were greater $(p<0.05)$ in the broadcast plots than the injection or control plots. Pseudoscorpiones were more abundant $(p<0.05)$ in the injection treatment compared to the broadcast and control treatments. Acari populations and the QBS index were not significantly impacted by manure application.
\end{abstract}

\section{Keywords}

Soil, Arthropod, Manure, Nutrients, Swine Slurry, Soil Health, Soil Properties

\section{Introduction}

Agricultural soil health is a complex concept lacking a simple, direct method of measurement, making it difficult to quantify or categorize. Generally, the term "soil quality" refers to physical and chemical soil characteristics while the term "soil health" also includes information about the biological well-being of the edaphic environment [1]. The soil biotic community, soil type, and the amount and availability of nutrients all play an important role in soil health [2]. 
Soil arthropod abundance and diversity can provide information about the biological response of soil to environmental changes [3] [4] due to the strong degree of sensitivity among arthropods to land management practices [5] and the positive correlation to soil health of specific taxa [4]. The relative adaption of arthropod taxa to the soil environment can be quantified using the QBS method ("Qualità Biologica del Suolo," or "Biological Index of Soil Quality") based upon an eco-morphological index (EMI) score from 1 to 20 that accounts for factors including arthropod pigmentation, appendage and visual apparatus development, and total body size, among others.

Mites (Acari) and springtails (Collembola) are two of the most abundant and diverse commonly represented soil arthropod orders and are ubiquitous in most agroecosystems [6] [7] [8]. These and other soil arthropods serve as links in the middle of the food chain, acting as both predators and prey [8] [9] with some species contributing to organic matter decomposition and cycling of nutrients, improvement of soil structure, and growth of plants [2] [10] [11] [12] [13]. Monitoring changes in abundance and diversity of arthropods may reveal valuable information about the ecological health of soil in response to external stimuli.

Application of livestock manure to agricultural fields is a common method of enhancing soil fertility in crop production systems. Understanding the impact of manure addition and application method on soil biology is an important step towards improving the value and desirability of manure for agricultural cropping systems. This study focused on assessing the impact of swine slurry application method and time following slurry application on soil chemical properties and arthropod abundance and diversity for a period of one year.

\section{Materials and Methods}

\subsection{Site Description}

This field study was conducted at the University of Nebraska-Lincoln Rogers Memorial Farm (Latitude 40.8484662, Longitude 96.4664023) $18 \mathrm{~km}$ east of Lincoln, Nebraska, USA, from June 2014 through June 2015. Soil at the site is classified as an Aksarben silty clay loam (fine, smectitic, mesic Typic Argiudoll), containing 3.5\% OM and 1.5\% total carbon [14]. The site has been operated under a no-till management system using a crop rotation of corn (Zea mays L.), grain sorghum (Sorghum bicolor (L.) Moench), soybean (Glycine max (L.) Merr.), and winter wheat (Triticum aestivum L. cv. Pastiche) and had remained fallow following a corn crop harvested in October 2013. Manure had not been applied to the site since at least 1966 . Herbicide (glyphosate) was applied as necessary to manage weed growth. Daily precipitation data was gathered from the Lincoln 85 ENE, NE weather station, and daily temperature was obtained from the Syracuse, NE US weather station, located approximately 4 and $30 \mathrm{~km}$ from the Rogers Memorial Farm, respectively. 


\subsection{Plot Preparation}

Experimental treatments included two manure application methods (broadcast and injected) and a control. Four $0.75 \mathrm{~m} \times 2 \mathrm{~m}$ plots were assigned to each treatment and established with the $2-\mathrm{m}$ plot dimension parallel to the slope in the direction of overland flow. Due to site design and manure application equipment, a randomized complete block design was not possible. Arrangement of treatments along a single field contour allowed for consistent soil properties across all plots. Swine slurry collected from the deep pits of an 8000-head commercial wean-to-finish swine facility in eastern Nebraska were analyzed at a commercial laboratory. Mean measured values of nitrate nitrogen $\left(\mathrm{NO}_{3}-\mathrm{N}\right)$, ammonium $\left(\mathrm{NH}_{4}-\mathrm{N}\right)$, total nitrogen (TN), total phosphorous (TP), water content, electrical conductivity (EC), and $\mathrm{pH}$ for the slurry were $3.91 \mathrm{~g} \cdot \mathrm{kg}^{-1}, 0.0024$ $\mathrm{g} \cdot \mathrm{kg}^{-1}, 5.49 \mathrm{~g} \cdot \mathrm{kg}^{-1}, 0.58 \mathrm{~g} \cdot \mathrm{kg}^{-1}, 96.57 \%, 42.35 \mathrm{dS} \cdot \mathrm{m}^{-1}$, and 8.0 , respectively. Slurry was applied by a commercial operator on June 30, 2014. For injection, a $\mathrm{v}$-shaped chisel (horizontal sweep) implement was used on a 6-row applicator for manure placement to a depth of approximately $15 \mathrm{~cm}$. For broadcast application, the operator lifted the injection apparatus above the soil while maintaining a constant speed and flow rate to distribute the manure on the soil surface. Slurry for both treatments was applied at a rate of approximately $46,800 \mathrm{~L} \cdot \mathrm{ha}^{-1}$. Control plots did not receive any application of manure.

\subsection{Soil Sample Collection}

Two types of soil samples were collected twelve days prior to treatment applications, one- and three-week post-application of manure, and every four weeks, thereafter, throughout the study period except when soil was frozen in December 2014 and January, February, and March 2015. The two types of soil samples collected were: 1) 3.8-cm diameter samples collected with a soil probe to a depth of $20 \mathrm{~cm}$ and subsequently divided into $0-10$ and $10-20 \mathrm{~cm}$ sections, which underwent nutrient analysis at a commercial laboratory; and 2) samples measuring $20 \mathrm{~cm}$ in diameter and depth $\left(6280 \mathrm{~cm}^{3}\right)$ collected for arthropod extraction. Laboratory analyses included $\mathrm{pH}, \mathrm{EC}$, percent organic matter $(\mathrm{OM})$, $\mathrm{NO}_{3}-\mathrm{N}, \mathrm{P}$, potassium $(\mathrm{K})$, calcium $(\mathrm{Ca})$, magnesium $(\mathrm{Mg})$, sodium $(\mathrm{Na})$, sulfur $\left(\mathrm{SO}_{4}-\mathrm{S}\right)$, and cation exchange capacity (CEC). Samples collected for arthropod extraction were stored in plastic buckets with air holes in the lids, placed in coolers with ice packs, and transported to the University of Nebraska-Lincoln West Central Research \& Extension Center in North Platte, Nebraska within $12 \mathrm{~h}$ of collection. Samples were transferred to Berlese-Tullgren funnels for extraction of arthropods, a commonly used technique to assess arthropods in the soil [15]. A $70 \%$ ethanol solution was used to preserve the organisms for later analysis.

\subsection{Arthropod Sample Analyses}

The QBS method of classification was employed to assign an eco-morphological index (EMI) score from 1 to 20 on the basis of soil adaptability level of each 
arthropod order or family [4]. Preserved arthropods from each soil sample were identified and quantified using a Leica EZ4 stereo microscope (Leica Biosystems, Inc., Buffalo Grove, IL) and a dichotomous key [16]. Arthropods were classified to order or family based on the level of taxonomic resolution necessary to assign an EMI value as described by Parisi et al. [4]. For some groups, such as Coleoptera, characteristics of edaphic adaptation were used to assign individual EMI scores.

\subsection{Statistical Analyses}

The impacts of swine slurry application method and time following manure application on soil arthropod populations and soil chemical characteristics was determined by performing tests of hypotheses for mixed model analysis of variance using the general linear model (GLM) procedure [17]. The samples were tested for significant differences resulting from time and treatment, application method, samples within treatments, soil depth and interactions among these factors. Following identification of any significant differences, the least significant differences (LSD) test was employed to identify specific differences among treatments. $P<0.05$ was considered significant.

\section{Results and Discussion}

\subsection{Soil Characteristics}

Manure application method affected all measured soil characteristics (Table 1). Differences in some soil characteristics (e.g. P, $\mathrm{K}, \mathrm{SO}_{4}-\mathrm{S}$ ) between manure application methods were likely due to the location of soil sampling. Since soil was collected between the injection slots, it is likely that slurry had not been placed at the sampling location. Time since application and sampling depth also had an effect on all measured soil characteristics. The interaction of treatment $\mathrm{x}$ time was significant for all characteristics except $\mathrm{OM}$ while the interaction of treatment $x$ depth was significant for all characteristics except $\mathrm{NO}_{3}-\mathrm{N}$.

The $\mathrm{pH}$ for the $10-20 \mathrm{~cm}$ depth on the broadcast treatment and for the $0-10$ $\mathrm{cm}$ depth on the broadcast and control treatments were greater than for the injection treatment (Table 1). The $\mathrm{pH}$ at $10-20 \mathrm{~cm}$ depth was the greatest in the broadcast treatment. Over time, $\mathrm{pH}$ in the broadcast plot remained fairly stable, only varying between 6.5 and 7.0 (Figure 1). In contrast, the injection and control treatments had greater variations in $\mathrm{pH}$ over time, varying from 5.6 to 6.8 and 6.1 to 6.9, respectively. Previous results of the effect of swine manure on soil $\mathrm{pH}$ have been mixed with authors citing increases, decreases, and no change [18] [19] [20] [21].

$\mathrm{OM}$ was greater in the control and broadcast treatments when compared to the injection treatment (Table 1). OM in the injection treatment was also less in the top $10 \mathrm{~cm}$ depth than the broadcast or control treatments. It is possible that disturbance of the soil surface during injection reduced OM in that treatment. It is well documented that tillage reduces OM [22] [23]. There were no differences 
Table 1. Soil characteristics as affected by swine slurry application method, soil depth, and time following application.

\begin{tabular}{|c|c|c|c|c|c|c|c|c|c|c|c|}
\hline & \multirow{2}{*}{$\mathrm{pH}$} & $\mathrm{EC}$ & $\mathrm{OM}$ & $\mathrm{NO}_{3}-\mathrm{N}$ & $\mathrm{P}$ & $\mathrm{K}$ & $\mathrm{Ca}$ & $\mathrm{Mg}$ & $\mathrm{Na}$ & $\mathrm{SO}_{4}-\mathrm{S}$ & CEC \\
\hline & & $\mathrm{mmho} \cdot \mathrm{cm}^{-1}$ & $\%$ & $\mathrm{mg} \cdot \mathrm{kg}^{-1}$ & $\mathrm{mg} \cdot \mathrm{kg}^{-1}$ & $\mathrm{mg} \cdot \mathrm{kg}^{-1}$ & $\mathrm{mg} \cdot \mathrm{kg}^{-1}$ & $\mathrm{mg} \cdot \mathrm{kg}^{-1}$ & $\mathrm{mg} \cdot \mathrm{kg}^{-1}$ & $\mathrm{mg} \cdot \mathrm{kg}^{-1}$ & me $100 \mathrm{~g}^{-1}$ \\
\hline \multicolumn{12}{|l|}{ Treatment (TRT) } \\
\hline Injection & $6.21^{\mathrm{b}}$ & $0.39^{\mathrm{ab}}$ & $2.9^{\mathrm{b}}$ & $16.8^{\mathrm{a}}$ & $18.4^{\mathrm{b}}$ & $286.6^{c}$ & $3087.3^{\mathrm{b}}$ & $670.6^{a}$ & $17.9^{\mathrm{a}}$ & $9.9^{\mathrm{b}}$ & $23.7^{\mathrm{a}}$ \\
\hline Broadcast & $6.63^{\mathrm{a}}$ & $0.40^{\mathrm{a}}$ & $3.3^{\mathrm{a}}$ & $15.2^{\mathrm{a}}$ & $44.4^{\mathrm{a}}$ & $411.5^{\mathrm{a}}$ & $3181.1^{\mathrm{b}}$ & $425.9^{c}$ & $11.3^{\mathrm{b}}$ & $11.8^{\mathrm{a}}$ & $21.8^{\mathrm{b}}$ \\
\hline \multicolumn{12}{|l|}{$\underline{\text { Depth } \times \text { TRT }}$} \\
\hline \multicolumn{12}{|l|}{$0-10 \mathrm{~cm}$} \\
\hline Injection & $6.38^{\mathrm{b}}$ & $0.44^{\mathrm{b}}$ & $3.2^{\mathrm{b}}$ & $22.3^{\mathrm{a}}$ & $29.7^{\mathrm{b}}$ & $321.5^{\mathrm{c}}$ & $3082.5^{c}$ & $564.4^{\mathrm{a}}$ & $16.4^{\mathrm{a}}$ & $12.1^{\mathrm{b}}$ & 22.4 \\
\hline Broadcast & $7.08^{\mathrm{a}}$ & $0.49^{\mathrm{a}}$ & $3.7^{\mathrm{a}}$ & $20.7^{\mathrm{a}}$ & $64.4^{\mathrm{a}}$ & $510.2^{\mathrm{a}}$ & $3415.7^{\mathrm{b}}$ & $387.3^{c}$ & $12.9^{\mathrm{b}}$ & $13.3^{\mathrm{a}}$ & 21.8 \\
\hline \multicolumn{12}{|l|}{$10-20 \mathrm{~cm}$} \\
\hline Injection & $6.04^{\mathrm{b}}$ & $0.34^{\mathrm{a}}$ & $2.5^{\mathrm{c}}$ & $11.4^{\mathrm{a}}$ & $7.0^{\mathrm{b}}$ & $251.8^{\mathrm{c}}$ & $3092.1^{\mathrm{b}}$ & $776.8^{\mathrm{a}}$ & $19.4^{\mathrm{a}}$ & $7.7^{\mathrm{b}}$ & $25.1^{\mathrm{a}}$ \\
\hline Broadcast & $6.18^{\mathrm{a}}$ & $0.32^{\mathrm{ab}}$ & $3.0^{\mathrm{b}}$ & $9.6^{\mathrm{ab}}$ & $24.4^{\mathrm{a}}$ & $312.8^{\mathrm{a}}$ & $2946.5^{c}$ & $464.6^{c}$ & $9.7^{\mathrm{b}}$ & $10.4^{\mathrm{a}}$ & $21.9^{\mathrm{b}}$ \\
\hline Control & $5.94^{\mathrm{b}}$ & $0.30^{\mathrm{b}}$ & $3.2^{\mathrm{a}}$ & $7.3^{\mathrm{b}}$ & $8.0^{\mathrm{b}}$ & $275.3^{\mathrm{b}}$ & $3305.4^{\mathrm{a}}$ & $638.2^{\mathrm{b}}$ & $10.9^{b}$ & $9.6^{\mathrm{a}}$ & $25.8^{\mathrm{a}}$ \\
\hline$\underline{\mathrm{GLM}}$ & \multicolumn{11}{|c|}{$\operatorname{Pr}>F$} \\
\hline TRT & $<0.01$ & 0.05 & $<0.01$ & 0.01 & $<0.01$ & $<0.01$ & 0.01 & $<0.01$ & $<0.01$ & 0.02 & 0.03 \\
\hline Rep (TRT) & $<0.01$ & 0.06 & 0.03 & 0.14 & $<0.01$ & $<0.01$ & $<0.01$ & $<0.01$ & 0.02 & $<0.01$ & $<0.01$ \\
\hline Time & $<0.01$ & $<0.01$ & $<0.01$ & $<0.01$ & $<0.01$ & $<0.01$ & $<0.01$ & $<0.01$ & $<0.01$ & $<0.01$ & $<0.01$ \\
\hline Depth & $<0.01$ & $<0.01$ & $<0.01$ & $<0.01$ & $<0.01$ & $<0.01$ & $<0.01$ & $<0.01$ & 0.02 & $<0.01$ & $<0.01$ \\
\hline TRT $^{\star}$ Time & $<0.01$ & $<0.01$ & 0.07 & $<0.01$ & $<0.01$ & $<0.01$ & $<0.01$ & 0.01 & $<0.01$ & $<0.01$ & $<0.01$ \\
\hline TRT ${ }^{\star}$ Depth & $<0.01$ & 0.03 & $<0.01$ & 0.10 & $<0.01$ & $<0.01$ & $<0.01$ & $<0.01$ & $<0.01$ & 0.02 & $<0.01$ \\
\hline TRT ${ }^{*}$ Time $^{*}$ Depth & 0.46 & 0.72 & 0.26 & 0.57 & 0.50 & 0.87 & 0.90 & 0.82 & 0.43 & 0.14 & 0.55 \\
\hline
\end{tabular}

${ }^{\dagger}$ In each section, data within a column with the same letter are not significantly different $(p>0.05)$.

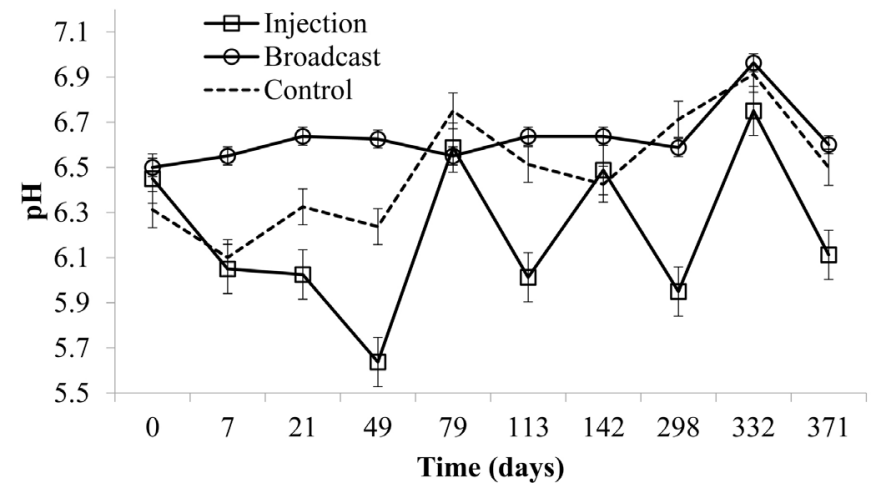

Figure 1. Mean soils $\mathrm{pH}$ at 10 to $20 \mathrm{~cm}$ soil depth as affected by time for the injection applied swine slurry, broadcast applied swine slurry, and non-manure control treatments; day 0 represents the pre-treatment value. Error bars represent standard errors.

in $\mathrm{OM}$ in the treatment $\times$ time interaction (Figure 2), which is expected given the short duration of this study. 
Both manure application methods increased soil $\mathrm{NO}_{3}-\mathrm{N}$ compared to the control treatment (Table 1). It is unsurprising that the treatment $\times$ depth interaction for $\mathrm{NO}_{3}-\mathrm{N}$ was not significant since nitrate is a mobile nutrient and both manure application methods applied nitrogen within the top $15 \mathrm{~cm}$ of soil. The interaction of treatment $\times$ time was significant, however. Concentrations of $\mathrm{NO}_{3}-\mathrm{N}$ in the broadcast treatment increased quickly and then gradually decreased over time, eventually tracking similarly to the control treatment. $\mathrm{NO}_{3}-\mathrm{N}$ concentration for the injection plots did not increase until approximately three months into the study, after which time they gradually decreased for the remainder of the experiment (Figure 3). This is most likely due to greater volatilization of ammonium from the broadcast manure, decreasing nitrate conversion.

\subsection{Arthropod Population Analyses}

A total of 13,311 arthropods representing 19 orders were identified, with Acari

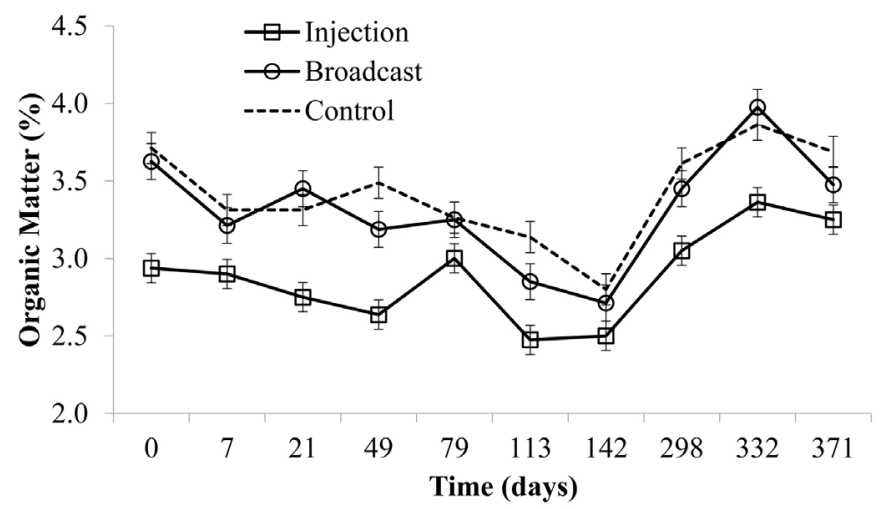

Figure 2. Mean soil organic matter (OM) content at 0 to $20 \mathrm{~cm}$ soil depth as affected by time for the injection applied swine slurry, broadcast applied swine slurry, and non-manured control treatments; day 0 represents the pre-treatment value. Error bars represent standard errors.

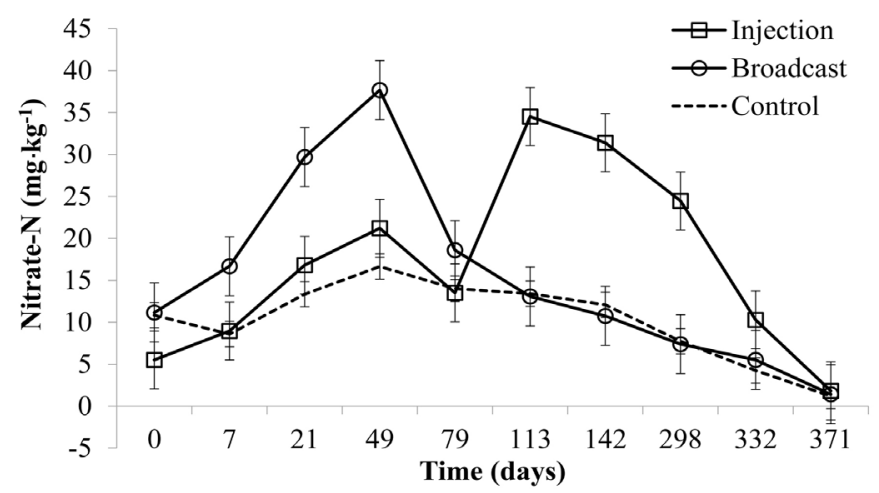

Figure 3. Mean soil nitrate-nitrogen $\left(\mathrm{NO}_{3}-\mathrm{N}\right)$ content at 0 to $20 \mathrm{~cm}$ soil depth as affected by time for the injection applied swine slurry, broadcast applied swine slurry, and non-manured control treatments; day 0 represents the pre-treatment value. Error bars represent standard errors. 
(38.7\% of total arthropods), Collembola: Isotomidae (26.8\%), Collembola: Hypogastruridae (10.4\%), Coleoptera larvae (1.6\%), Diplura (1.2\%), Diptera larvae (0.9\%), and Pseudoscorpiones (0.6\%) being the most abundant soil-dwelling taxa. Because these taxa were of greatest relative abundance in samples throughout the study, they were chosen for statistical analysis of their response to manure application method and time since application.

Hypogastruridae and Isotomidae abundances increased more markedly in the broadcast treatment (Table 2) while Pseudoscorpiones were more abundant in the injection treatment throughout most of the post-manure application period of the study (Figure 4). The increase in Hypogastruridae and Isotomidae abundances in the broadcast plots agrees with studies reporting increased Collembola

Table 2. Selected arthropod taxa as affected by manure application method and time since application.

\begin{tabular}{|c|c|c|c|c|c|c|c|c|}
\hline & 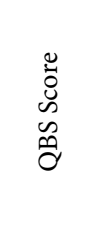 & 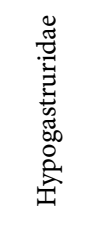 & 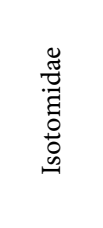 & $\overrightarrow{\widetilde{U}}$ & 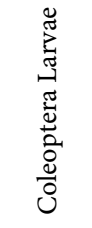 & $\frac{\widetilde{\Xi}}{\stackrel{\Xi}{\Xi}}$ & 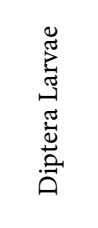 & 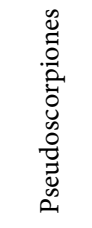 \\
\hline \multicolumn{9}{|l|}{$\underline{\text { Treatment }}$} \\
\hline Injection & 59.9 & $2.93^{\mathrm{b}}$ & $21.70^{\mathrm{b}}$ & 45.55 & 1.03 & 1.30 & 0.73 & $1.43^{\mathrm{a}}$ \\
\hline Broadcast & 59.6 & $20.88^{\mathrm{a}}$ & $52.18^{\mathrm{a}}$ & 40.88 & 2.25 & 1.25 & 0.88 & $0.18^{\mathrm{b}}$ \\
\hline Control & 57.2 & $10.68^{\mathrm{b}}$ & $15.20^{\mathrm{b}}$ & 42.20 & 1.93 & 1.30 & 1.25 & $0.38^{\mathrm{b}}$ \\
\hline \multicolumn{9}{|c|}{$\operatorname{Pr}>F$} \\
\hline Treatment & 0.8609 & 0.0016 & 0.0001 & 0.8828 & 0.3530 & 0.9800 & 0.7380 & 0.0030 \\
\hline Time & 0.0001 & 0.0001 & 0.0001 & 0.0001 & 0.0290 & 0.0001 & 0.0190 & 0.1960 \\
\hline Treatment $\times$ Time & 0.2687 & 0.0001 & 0.0001 & 0.1514 & 0.9140 & 0.0540 & 0.9460 & 0.5590 \\
\hline
\end{tabular}

${ }^{\dagger}$ In each section, data within a column with the same letter are not significantly different $(p>0.05)$.

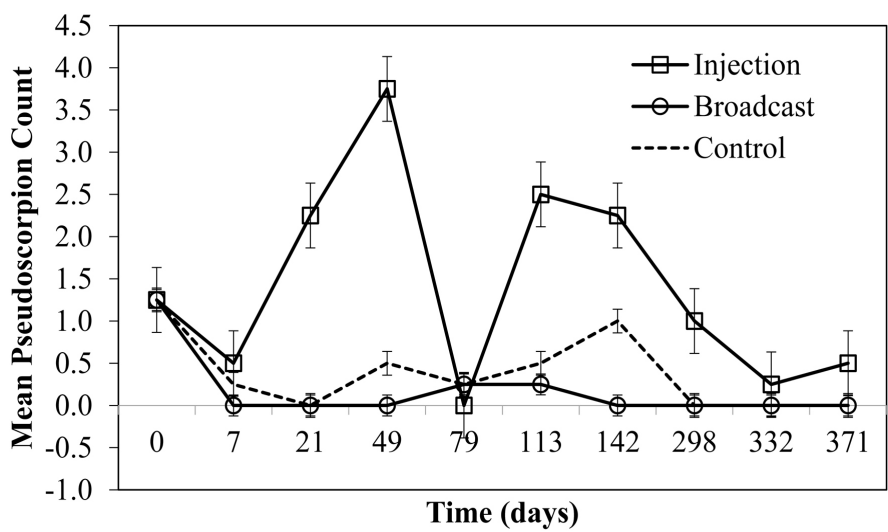

Figure 4. Mean Pseudoscorpiones count as affected by time since manure application for the injection applied swine slurry, broadcast applied swine slurry, and non-manured control treatments; day 0 represents the pre-treatment value. Error bars represent standard errors. 
abundance following addition of OM via manure application [24] [25]. Collembola abundance in the injection plots was not greater than in the control, despite the addition of OM in that treatment. Soil disturbance during manure injection may mitigate the positive impacts on arthropod populations from $\mathrm{OM}$ addition as other studies have reported reductions in arthropod abundance (reviewed in Wardle [26]), and particularly Collembola [24] following soil disturbance via tillage. On the contrary, broadcast application of swine slurry may have provided cover on the soil surface that mitigated drastic shifts in temperature and humidity [24], creating a more favorable environment for soil arthropods.

Time following slurry application impacted all measured arthropod populations except Pseudoscorpiones. Application method $\times$ time following application interactions were identified for Hypogastruridae and Isotomidae. Hypogastruridae abundance remained low in all plots until approximately 60 days into the study, at which time abundance increased sharply in the broadcast treatment (Figure 5). Hypogastruridae abundance peaked at 150 days in the broadcast and control plots before returning to quantities similar to those at the beginning of the study. Comparatively, Hypogastruridae abundance in the injection plots remained lower and much steadier throughout the study. Isotomidae abundance in the broadcast plots followed a similar trend to the Hypogastruridae, increasing rapidly after the first several months and then decreasing during winter months (Figure 6). Isotomidae abundance in the injection plots increased slightly two months after manure application, but less drastically than observed in the broadcast plots. Acari (mites) showed no response to the application of swine slurry, with time being the only significant variable for Acari abundance. This result was surprising, as other studies have reported increases in Acari abundance with OM addition to soil [24] [25]. Our samples were dominated by Orabatid mites, which regularly account for $60 \%-90 \%$ of all mites found at a given location [27]. Orabatid mites are characterized by a long life span, low

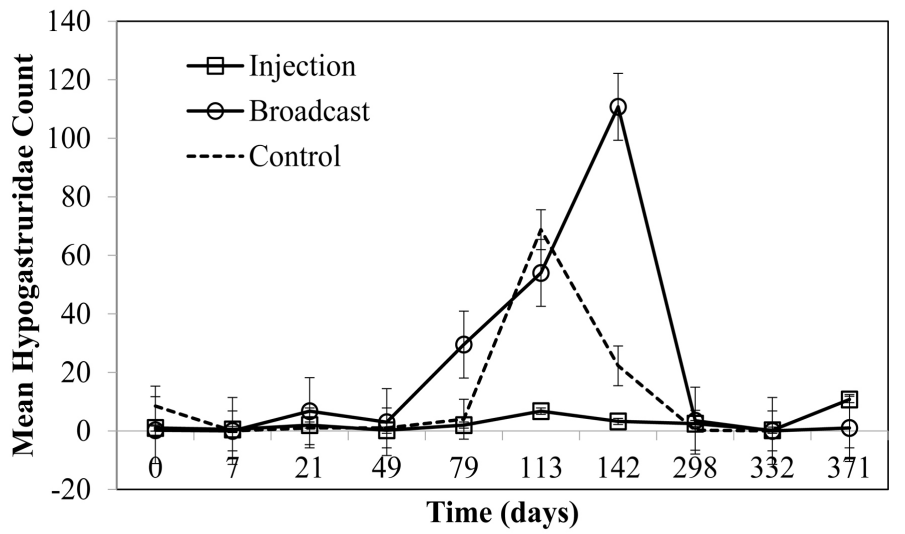

Figure 5. Mean Hypogasturidae count as affected by time since manure application for the injection applied swine slurry, broadcast applied swine slurry, and non-manured control treatments; day 0 represents the pre-treatment value. Error bars represent standard errors. 


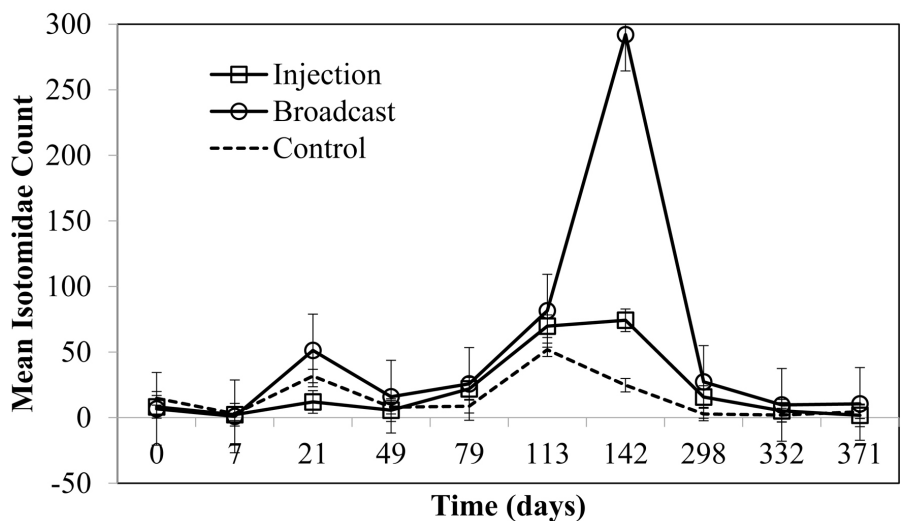

Figure 6. Mean Isotomidae count as affected by time since manure application for the injection applied swine slurry, broadcast applied swine slurry, and non-manured control treatments; day 0 represents the pre-treatment value. Error bars represent standard errors.

fecundity, slow development, and low dispersion ability, making them excellent bioindicators [27]. While total abundance of Acari was unaffected by treatment, community structure of this diverse group could have been affected but was not quantified in this study.

Overall arthropod community adaptation to soil-dwelling was quantified using the QBS index (Table 3). Although the QBS index has proven effective in evaluating soil biological health in a number of previous studies (e.g., [4] [28] [29], no significant differences in QBS indices were found among treatments in our study. Menta et al. [30] reported that the adoption of no till practices, but not the addition of manure or compost, increased the QBS index of soils in sorghum fields where increases in abundance of Acari were also observed. Parisi et al. [4] reported that QBS value correlated well with land use classes but was not impacted by sewage sludge application to soil. Soil disturbance was identified by Parisi et al. [4] as having a significant relationship to QBS value with arable land having lower QBS values than undisturbed and well-established wooded or shrubland areas. Because the land used in our study was under long-term no-till management, a difference in QBS indices among treatments was anticipated. However, this difference may not have been captured with our sampling methodology or the impact of a single manure application may have been overshadowed by many years of cropping activities. While manure application in our study did not improve QBS score, like previous studies [4] [30], application also did not negatively impact QBS score. Ultimately, similar to results found in a study by [31], the individual abundance of different arthropod groups seemed to serve as a better indicator of changes in soil characteristics in our study than the overall taxonomic richness.

Daily temperature and precipitation data from throughout the study were obtained from the nearest weather stations to the study site (Figure 7). Although arthropods can be sensitive to changes in soil moisture and temperature, the patterns observed for Hypogastruridae and Isotomidae in this study do not 
Table 3. QBS score over time by swine slurry application method.

\begin{tabular}{ccccccccccc}
\hline & \multicolumn{1}{c}{ QBS Score } \\
\hline Time (days) & Pre & 7 & 21 & 49 & 79 & 113 & 142 & 298 & 332 & 371 \\
Treatment & & & & & & & & & & \\
Injection & 71.0 & 47.0 & 90.0 & 76.0 & 42.0 & 52.0 & 59.5 & 61.3 & 49.3 & 50.8 \\
Broadcast & 78.3 & 43.0 & 87.3 & 63.3 & 58.3 & 66.5 & 50.8 & 61.0 & 49.0 & 39.0 \\
Control & 90.3 & 39.8 & 62.3 & 76.5 & 64.3 & 75.3 & 48.5 & 28.8 & 43.3 & 43.5 \\
\hline
\end{tabular}

${ }^{\dagger}$ No statistical differences were found among QBS scores.

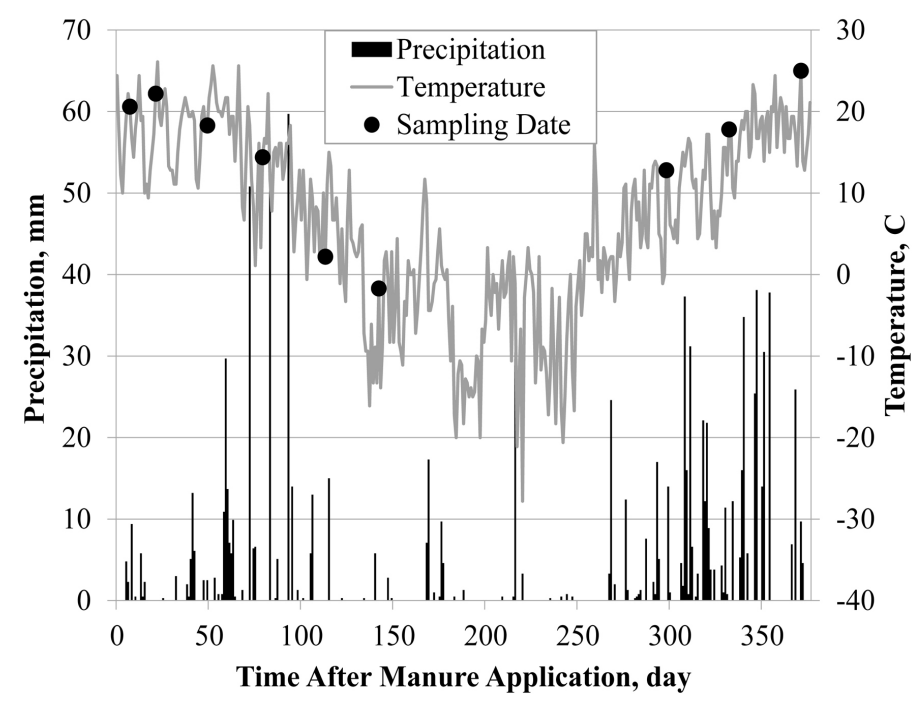

Figure 7. Daily rainfall $(\mathrm{mm})$ and temperature $\left({ }^{\circ} \mathrm{C}\right)$ during the study period; day 0 represents the pre-treatment value.

appear to be correlated with these abiotic conditions. Spikes in Hypogastruridae and Isotomidae abundances in the broadcast treatment 142 days after manure application (Figure 5 \& Figure 6) did not correspond with intense or frequent rainfall events or high temperatures (Figure 7).

Differences in $\mathrm{pH}$ among treatments may have influenced Collembola and other arthropod populations. Collembolans are strongly sensitive to changes in $\mathrm{pH}$ [32]. The broadcast plots offered a higher $\mathrm{pH}$ environment (6.63) than the injection treatment (6.21) and control (6.48). Ke et al. [32] reported that collembolans showed preference for higher $\mathrm{pH}$-typically preferring approximately pH 8.0- which agrees with our results.

Few studies have examined the soil arthropod community in agroecosystems following application of swine slurry as our study did. The use of dairy cattle slurry in agricultural systems has been examined in Europe: Leroy et al. [25] found that addition of dairy cattle slurry in Belgium increased collembolan and mite populations, while Jagers op Akkerhuis et al. [33] reported that broadcast application of dairy cattle slurry enhanced soil surface-dwelling arthropods more so than injection in The Netherlands. In southern Brazil, swine slurry application has been found to increase soil macrofauna diversity [34] and, in particular, 
resulted in a greater abundance of Collembola in no-till agricultural soils at rates of 40 or $80 \mathrm{~m}^{3} \cdot \mathrm{ha}^{-1}$ [35]. These results correspond with our study where swine slurry was applied at a similar rate of $46.8 \mathrm{~m}^{3} \cdot \mathrm{ha}^{-1}\left(46,800 \mathrm{~L} \cdot \mathrm{ha}^{-1}\right)$.

\section{Conclusions}

Swine slurry application to agricultural fields serves as a beneficial fertilizer source that improves soil properties. Method of manure application and time following application may result in varying changes in soil characteristics. This study investigated the effect of application method and time following application on soil arthropod abundance and diversity. The most significant responses to application method were found for collembolan populations, specifically $\mathrm{Hy}$ pogastruridae and Isotomidae, with both increasing under broadcast application of swine slurry. Pseudoscorpiones were more abundant in the injection treatment throughout most of the post-manure application period of the study. Time following slurry application impacted most of the analyzed populations including Hypogastruridae, Isotomidae, mites, coleopteran larvae, diplurans, and dipteran larvae. The positive response of Hypogastruridae and Isotomidae to broadcast slurry application was likely due to the addition of nutrients (in the form of $\mathrm{OM}$ and nitrates) to the soil provided by this form of agricultural fertilizer. Hypogastruridae abundance remained low in all plots until approximately 60 days into the study, at which time abundance increased sharply in the broadcast and control treatments, peaking at about 115 to 150 days in the broadcast and control plots, respectively, before returning to quantities similar to those at the beginning of the study. Hypogastruridae abundance in the injection plots remained lower and much steadier throughout the study. Isotomidae abundance in the broadcast plots followed a similar trend to the Hypogastruridae. Isotomidae abundance in the injection plots increased slightly two months after manure application, but less drastically than observed in the broadcast plots. Total abundance of Acari (mites) showed no response to the application of swine slurry; however, community structure of this diverse group-dominated in our study by Orabatid mites-may have been affected but was not quantified in this study. Soil chemical characteristics

$\mathrm{OM}$ was greater in the control and broadcast treatments when compared to the injection treatment, which likely contributed to greater collembolan populations in these treatments. Soil disturbance by injection equipment may have mitigated any positive impacts on arthropod populations from OM addition.

The utilization of swine slurry as a fertilizer source is beneficial to soil health, but requires consideration of application method, time following slurry application, and the combination of those two factors that will influence the soil micro-organisms present in the soil environment.

\section{Acknowledgements}

Eric Davis, Ethan Doyle, Mitchell Goedeken, Stuart Hoff, Kevan Reardon, and 
Lucas Snethen are gratefully acknowledged for their assistance with field data collection. Kayla Mollet, Ethan Doyle, and Ashley Schmit are acknowledged for their assistance with data processing.

\section{Conflicts of Interest}

The authors declare no conflicts of interest regarding the publication of this paper.

\section{Funding}

This work was supported, in part, by faculty research funds provided by the Agricultural Research Division within the University of Nebraska-Lincoln Institute of Agriculture and Natural Resources.

\section{References}

[1] Curell, C., Gross, P. and Steinke, K. (2012) Soil Health and Soil Quality: Understanding the Differences between Soil Health and Soil Quality. Michigan State University Extension, East Lansing, MI. http://www.msue.msu.edu/

[2] Kibblewhite, M.G., Ritz, K. and Swift, M.J. (2008) Soil Health in Agricultural Systems. Philosophical Transactions of the Royal Society London B, 363, 685-701.

[3] Pankhurst, C.E., Hawke, B.G., McDonald, H.J., Kirkby, C.A., Bakerfield, J.C., Michelsen, P., O'Brien, K.A., Gupta, V.V.S.R. and Doube, B.M. (1995) Evaluation of Soil Biological Properties as Potential Bioindicators of Soil Health. Australian Journal of Experimental Agriculture, 35, 1015-1028. https://doi.org/10.1071/EA9951015

[4] Parisi, V., Menta, C., Gardi, C., Jacomini, C. and Mozzanica, E. (2005) Microarthropod Communities as a Tool to Assess Soil Quality and Biodiversity: A New Approach in Italy. Agriculture, Ecosystems \& Environment, 105, 323-333. https://doi.org/10.1016/j.agee.2004.02.002

[5] Sapkota, T.B., Mazzoncini, M., Bárberi, P., Antichi, D. and Silvestri, N. (2012) Fifteen Years of No Till Increase Soil Organic Matter, Microbial Biomass and Arthropod Diversity in Cover Crop-Based Arable Cropping Systems. Agronomy for Sustainable Development, 38, 853-863. https://doi.org/10.1007/s13593-011-0079-0

[6] Hendrix, P.F., Parmellee, R.W., Crossley, D.A., Coleman, D.C., Odum, E.P. and Groffman, P.M. (1986) Detritus Food Webs in Conventional and No-Tillage Agroecosystems. Bioscience, 36, 374-380. https://doi.org/10.2307/1310259

[7] Crossley, D.A., Mueller, B.R. and Perdue, J.C. (1992) Biodiversity of Microarthropods in Agricultural Soils: Relations to Processes. Agriculture, Ecosystems \& Environment, 40, 37-46. https://doi.org/10.1016/0167-8809(92)90082-M

[8] Culliney, T.W. (2013) Role of Arthropods in Maintaining Soil Fertility. Agriculture, 3, 629-659. https://doi.org/10.3390/agriculture3040629

[9] Booher, E.C.J., Greenwood, C.M. and Hattey, J.A. (2012) Effects of Soil Amendments on Soil Microarthropods in Continuous Maize in Western Oklahoma. Southwestern Entomologist, 37, 23-30. https://doi.org/10.3958/059.037.0103

[10] Schulz, E. and Scheu, S. (1994) Oribatid Mite Mediated Changes in Litter Decomposition: Model Experiments with 14C-Labelled Holocellulose. Pedobiologia, 38, 344-352.

[11] van Straalen, N.M. (1997) Community Structure of Soil Arthropods as a Bioindicator 
of Soil Health. In: Pankhurst, C., Doube, B.M. and Gupta, V.V.S.R., Eds., Biological Indicators of Soil Health, CAB International, New York, 235-264.

[12] Bradford, M.A., Eggers, T., Newington, J.E. and Tordoff, G.M. (2007) Soil Faunal Assemblage Composition Modifies Root In-Growth to Plant Litter Patches. Pedobiologia, 50, 505-513. https://doi.org/10.1016/j.pedobi.2006.07.001

[13] Huhta, V. (2007) The Role of Soil Fauna in Ecosystems: A Historical Review. Pedobiologia, 50, 489-495. https://doi.org/10.1016/j.pedobi.2006.08.006

[14] Kettler, T.A., Doran, J.W. and Gilbert, T.L. (2001) Simplified Method for Soil Particle-Size Determination to Accompany Soil-Quality Analyses. Soil Science Society of America Journal, 65, 849-852. https://doi.org/10.2136/sssaj2001.653849x

[15] Ducarme, X., André, H.M. and Lebrun, P.H. (2002) Soil Biodiversity: Myth, Reality or Conning? Oikos, 96, 3-24. https://doi.org/10.1034/j.1600-0706.2002.11216.x

[16] Triplehorn, C.A. and Johnson, N.F. (2004) Borror and DeLong's Introduction to the Study of Insects. 7th Edition, Brooks Cole, Pacific Grove.

[17] (2015) Statistical Analysis Software (SAS). 4th Edition, SAS Institute Inc., Cary.

[18] Safley, L.M., Lessman, G.M., Wolt, J.D. and Smith, M.C. (1980) Comparison of Corn Yields between Broadcast and Injected Applications of Swine-Manure Slurry. Tennessee Farm and Home Science: Progress Report, 114, 20-22.

[19] Plaza, C., Senesi, N., García-Gil, J.C., Brunetti, G., D’Orazio, V. and Polo, A. (2002) Effects of Pig Slurry Application on Soils and Soil Humic Acids. Journal of Agricultural and Food Chemistry, 50, 4867-4874. https://doi.org/10.1021/jf020195p

[20] Adeli, A., Bolster, C.H., Rowe, D.E., McLaughlin, M.R. and Brink, G.E. (2008) Effect of Long-Term Swine Effluent Application on Selected Soil Properties. Soil Science, 173, 223-235. https://doi.org/10.1097/ss.0b013e31816408ae

[21] Ahmed, S.I., Mickelson, S.K., Pederson, C.H., Baker, J.L., Kanwar, R.S., Lorimor, J.C. and Webber, D. (2013) Swine Manure Rate, Timing, and Application Method Effects on Post-Harvest Soil Nutrients, Crop Yield, and Potential Water Quality Implications in a Corn-Soybean Rotation. Transactions of the ASABE, 56, 395-408. https://doi.org/10.13031/2013.42678

[22] Reicosky, D.C., Kemper, W.D., Langdale, G., Douglas, C.L. and Rasmussen, P.E. (1995) Soil Organic Matter Changes Resulting from Tillage and Biomass Production. Journal of Soil and Water Conservation, 50, 253-261.

[23] Six, J., Elliott, E.T. and Paustian, K. (1999) Aggregate and Soil Organic Matter Dynamics under Conventional and No-Tillage Systems. Soil Science Society of America Journal, 63, 1350-1358. https://doi.org/10.2136/sssaj1999.6351350x

[24] Miyazawa, K., Tsuji, H., Yamagata, M., Nakano, H. and Nakamoto, T. (2002) The Effects of Cropping Systems and Fallow Managements on Microarthropod Populations. Plant Production Science, 5, 257-265. https://doi.org/10.1626/pps.5.257

[25] Leroy, B.L.M.M., Bommele, L., Reheul, D., Moens, M. and De Neve, S. (2007) The Application of Vegetable, Fruit, and Garden Waste (VFG) Compost in Addition to Cattle Slurry in a Silage Maize Monoculture: Effects on Soil Fauna and Yield. European Journal of Soil Biology, 43, 91-100. https://doi.org/10.1016/j.ejsobi.2006.10.005

[26] Wardle, D.A. (1995) Impacts of Disturbance on Detritus Food Webs in Agro-Ecosystems of Contrasting Tillage and Weed Management Practices. Advances in Ecological Research, 26, 105-185. https://doi.org/10.1016/S0065-2504(08)60065-3

[27] Gulvik, M.E. (2007) Mites (Acari) as Indicators of Soil Biodiversity and Land Use Monitoring: A Review. Polish Journal of Ecology, 55, 415-440. 
[28] Gardi, C., Tomaselli, M., Parisi, V., Petraglia, A. and Santini, C. (2002) Soil Quality Indicators and Biodiversity in Northern Italian Permanent Grasslands. European Journal of Soil Biology, 38, 103-110. https://doi.org/10.1016/S1164-5563(01)01111-6

[29] Elia, E., Bianchi, A., Ferrazzi, P., Bergström, R., Danell, K., Chamberlain, D. and Persson, I.L. (2010) Impacts of Moose (Alces alces) at Different Simulated Densities on Eco-Morphological Groups of Soil Mesofauna. Entomologica Fennica, 21, 168-180.

[30] Menta, C., Leoni, A., Tarasconi, K. and Affanni, P. (2010) Does Compost Use Affect Microarthropod Soil Communities? Fresenius Environmental Bulletin, 19, 2303-2311.

[31] Santorufo, L., Van Gestel, C.A.M., Rocco, A. and Maisto, G. (2012) Soil Invertebrates as Bioindicators of Urban Soil Quality. Environmental Pollution, 161, 57-63. https://doi.org/10.1016/j.envpol.2011.09.042

[32] Ke, X., Yang, Y., Yin, W. and Xue, L. (2004) Effects of Low pH Environment on the Collembolan Onychiurus Yaodai. Pedobiologia, 48, 545-550. https://doi.org/10.1016/j.pedobi.2004.07.001

[33] Jagers op Akkerhuis, G.A.J.M., Dimmers, W.J., van Vliet, P.C.J., Goedhart, P.W., Martakis, G.F.P. and de Goede, R.G.M. (2008) Evaluating the Use of Gel-Based Sub-Sampling for Assessing Responses of Terrestrial Microarthropods (Collembola and Acari) to Different Slurry Applications and Organic Matter Contents. Applied Soil Ecology, 38, 239-248.

[34] Cherubin, M.R., Eitelwein, M.T., Fabbris, C., Weirich, S.W., da Silva, R.F., da Silva, V.R. and Basso, C.J. (2015) Physical, Chemical, and Biological Quality in an Oxisol under Different Tillage and Fertilizer Sources. Revista Brasileira de Ciência do Solo, 39, 615-625. https://doi.org/10.1590/01000683rbcs20140462

[35] da Silva, R.F., Bertollo, G.M., Corassa, G.M., Cocco, L.B., Steffen, R.B. and Basso, C.J. (2014) Doses of Liquid Swine Slurry on Soil Biota Community under No Tillage and Minimum Tillage. Ciência Rural, 44, 418-424. 